JPIF

35,4

\title{
Editorial
}

354

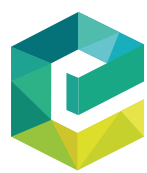

Journal of Property Investment \& Finance

Vol. 35 No. 4, 2017 pp. $354-355$

(C) Emerald Publishing Limite 1463-578X

DOI 10.1108/JPIF-05-2017-0039

\section{The valuation of sustainability}

If, at the date of valuation, the market does not differentiate "sustainable" and "non-sustainable", there will be no impact on value (www.rics.org/sustainability).

"Sustainability" is a funny thing. In the last 15 years, I don't think that there has been a bigger buzzword for the property profession than the word "sustainability" particularly when discussing the value of buildings. Now don't get me wrong, I am not in the Trump camp of suggesting that there is no such thing as global warming. I tend to think that is if the majority of scientists around the world agree that the world is heating up, then there is strong likelihood that the world is heating up.

The argument is about what is the influence of man on the process? Are our actions on lowering the carbon footprint of humankind too late or not needed at all? That is an area for debate.

But, I always found these arguments facile. Surely, the issue is that carbon fuels are finite and, as yet, green fuels have not been developed sufficiently to replace them. So regardless of the impact of the same on the environment, we should be developing strategies to use these fuels less so they last longer. It is just common sense.

But, despite laudable corporate social responsibility statements from all "the great and the good" companies from around the world, has the need to make buildings more energy efficient actually occurred? The answer with new builds, in the UK and other developed markets, is a resounding "yes". The answer with older, existing, stock is an equally deafening "no".

We won the green battle with new properties many years ago. All new buildings are ranked as BREEAM[1] Excellent or very good. All new buildings are energy efficient and rated as A or B on the Energy Performance Certificates (EPC) Certificates. I don't subscribe to a view that with new builds that there is a "green premium" or, conversely, a "green discount". The truth is that if everything is the same, then it is impossible to discern either. Sustainability is now just a specification and to allocate a rent or capital premium to the building makes as much sense as saying there is a premium for the building having windows. Occupiers of these buildings want and are offered a homogenous product and thus no developer will build a new non-sustainable building as it won't let and it won't sell. And the impact on value is indiscernible.

The problem is with existing buildings with lower EPC ratings. How do we get those retrofitted and improved? And what is the impact on value of a building being energy inefficient.

I have always believed in the adage that "markets sort themselves out" and so I thought with property retrofitting. If the cost savings are sufficient to compensate for the outlay over a reasonable payback period, then the market will retrofit. This is, obviously, a play between the cost of retrofitting falling (as it is done more and more and competition and economies of scale creeps into the market) and the price of energy increasing (to make the savings of a level that makes sense).

I thought that we had hit the tipping point in 2014, when energy prices were growing at almost exponential rates. Oil prices were at an all-time high in dollars per barrel. Natural gas was at numbers so high that the Norwegian and Russian economies were like bubbles filled with their own product. And, at that time, I saw that the potential cost savings (at current rates) far outstripped the cost of retrofitting. We were at that tipping point. 
Sadly, the energy cost bubble burst, in 2015 energy costs halved and the moment was gone. The market would not sort itself out. In a free market, sustainability will only have an impact if the occupiers of properties consider that the "sustainable elements" (energy savings) make a contribution (perceived or real) to the bottom line. Occupiers will only pay for specifications that impact positively upon their businesses. The numbers no longer stacked up.

And in terms of valuation, for the existing stock, the default setting tended to be "do nothing" and thus the impact on value was zero. Any impact on value would only happen if legislation is introduced that will restrict occupation. And this is exactly what has happened.

And although it shouldn't come as surprise, as it was announced in The Energy Act 2011, from April 2018 it will be unlawful to let residential or commercial properties with an EPC Rating of $\mathrm{F}$ or $\mathrm{G}$ (i.e. the lowest two grades of energy efficiency). That WILL have an impact on value. Properties that were previous let, at F and $\mathrm{G}$ ratings, will, at review, no longer be legally lettable. So the cash flow will end unless the property is retrofitted to bring its rating up to, at least, an E. No cash flow, no value. Apart from a residual based on refurbishment or redevelopment.

This will be discussed at length in a Practice Briefing in this journal later this year, but the issue needs to be flagged now. In fact, for some investors who have done nothing to date, it may already be too late. Any new legislation will have an impact in one of two ways. Either the restriction will impact on the value or it will instigate good property management initiatives to improve the existing stock. But, either way, sustainability is now more than a buzzword for the UK valuation profession. It is a tangible issue that will impact on the value or secondary and tertiary properties.

\section{Nick French}

\section{Note}

1. BREEAM is an environmental rating and sustainability assessment tool for buildings, master planning and infrastructure. 